\title{
The specificity of learning audition in the classes in english in the high education
}

\author{
Nigora KENJAEVA ${ }^{1}$ \\ Tashkent pharmaceutical institute
}

\begin{tabular}{l} 
ARTICLE INFO \\
\hline Article history: \\
Received March 2021 \\
Received in revised form \\
20 March 2021 \\
Accepted 15 April 2021 \\
Available online \\
20 May 2021 \\
\\
\hline Keywords: \\
english, \\
student, \\
training, \\
listening, \\
pronunciation, \\
letter, \\
intonation.
\end{tabular}

\begin{abstract}
The article related to teaching the perception of English speech in the listening classes in the high educational institutions is considered. The following components of the ability to perceive sounding speech are described: awareness of the phonetic phenomena of the English language; prosody as a means of organizing the structure of a sounding text; background knowledge of the listeners, providing an adequate understanding of the content of the message. Working with students in these areas is interpreted as a prerequisite for the successful formation of auditory competence.
\end{abstract}

2181-1415/C) 2021 in Science LLC.

This is an open access article under the Attribution 4.0 International (CC BY 4.0) license (https://creativecommons.org/licenses/by/4.0/deed.ru)

\section{Олий таълимда инглиз тилини ўқитишда тинглаб тушунишнинг ўзига хос хусусияти}

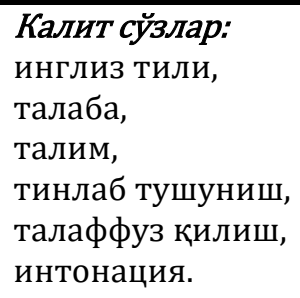

\begin{abstract}
АННОТАЦИЯ
Мақолада олий таълимда муассасалари талабаларга инглиз тилини тинглаб тушуниш орқали ўқитишнинг ўзига хос хусусиятлари, инглиз тили фонетик қоидаларидан билимга эга бўлиш, талабаларни эшитиш қобилиятларини шакллантириш тил ўрганишнинг зарурий шартларидан бири эканлиги талқин қилинади.
\end{abstract}

\footnotetext{
${ }^{1}$ Senior lecturer of the Tashkent pharmaceutical institute, Tashkent, Uzbekistan.
} 


\section{Специфика изучения аудирования на уроках английского языка в высшем образовании}

\author{
Ключевые слова: \\ английский язык, \\ студент, \\ обучение, \\ аудирование, \\ произношение, \\ буква, интонация.
}

\begin{abstract}
АННОТАЦИЯ
Статья посвящена изучению восприятия английской речи на уроках аудирования в высших учебных заведениях. Описаны следующие компоненты способности воспринимать звучащую речь: осведомленность о фонетических явлениях английского языка; просодия как средство организации структуры звучащего текста; фоновые знания слушателей, обеспечивающие адекватное понимание содержания сообщения. Работа со студентами по этим направлениям трактуется как необходимое условие успешного формирования слуховой компетенции.
\end{abstract}

Currently, a strategy has been adopted for teaching one type of speech activity through another, therefore, each of them acts as a learning goal and a means (for example, speaking while teaching reading). The purpose of teaching listening: the formation of listening skills for various types of speech (monologue and dialogical). Listening as a teaching tool is used:

1) as a way to introduce new linguistic material;

2) a means of memorizing linguistic material, in the process of creating durable auditory images of linguistic phenomena in unity with their meaning.

Learning to listen presents a number of challenges that are not always easy to overcome. One of these difficulties is the large gap between spelling and pronunciation in English. It is common knowledge that English spelling largely does not reflect the pronunciation norm. There is a big difference between what we see in writing and what we hear. The discrepancy between the written norm and pronunciation, and, first of all, the orientation towards written speech in the process of teaching Russian students is one of the factors that complicate the understanding of the spoken speech. Meanwhile, when analyzing the results of a survey conducted among first-year students of one of the technical specialties of the Polytechnic University, it was found that the overwhelming majorities not only do not know the rules of transcription, but also consider this knowledge to be absolutely unnecessary. Almost all students of technical specialties make mistakes in the pronunciation of foreign words, and this, of course, makes it difficult to understand oral speech. Students are not always able to correlate the word they see written on paper with its sound.

Other factors that make it difficult to understand spoken speech are the wide variability and variability of pronunciation in English. Thus, studying North American pronunciation, points not only to significant differences, especially in the pronunciation of vowel phonemes in regional variants, but also to sound changes occurring in the present tense [7]. This means that the problems in understanding perceived speech are objective. These problems are associated not only with the level of language proficiency, but also with its modern functioning. If we analyze the linguistic difficulties that students face when listening to a text in English, then the most noticeable of them are the following: a) inability to divide the speech stream into separate words. The most difficult to understand are sentences or phrases that contain abbreviated grammatical forms: it's all's taken place; would've been; Is'ther'pressure'd you think? The fast rate of utterance and the lack of variation in the melodic level of the utterance make them difficult to perceive; b) lack of understanding of such phonetic phenomena as elision, assimilation, the addition of unnecessary 
sounds. While listening to the texts, the students failed to understand the following phrases: - next to the window $\|$ due to the disappearance of [ $\mathrm{t}]$ into next $\|$, and they perceived this phrase as nexter the window\|. The sentence "I' $m$ walking to the tent" was interpreted as "I' $m$ walking to the dent (dentist)" because the aspiration [t] was not noticeable in the speaker's speech. When studying the errors and inaccuracies in the perception of the text in English, it is obvious that students often do not understand the correct speech. So, instead of the phrase "slip of the ear", a number of students heard: "slip of the year"; the phrase - the queen was keen to shelter the matter\| was heard as: the queen was king to shelter the matter||. The above examples require the teacher to develop a certain approach to explaining the phonetic features of the text that is being spoken. The teacher should create a system of exercises that will focus on: a) the ability to segment the speech stream; b) the ability to recognize a sounding word; c) the ability to find a correspondence between the sounding word and its written counterpart; d) the ability to restore abbreviated grammatical forms. The work on the perception of foreign speech should begin with teaching students the ability to determine by ear the sound structure of English words, regardless of their meaning. If a student is able to divide the listened text in a foreign language into separate words, then it can be argued that this student has a certain level of phonetic perception of the sounding text. A fairly large number of studies indicate the features of the boundary signals of words in English speech.

There are works indicating which phonemes are usually assigned to the initials and endings of English words. Researchers come to the conclusion that the beginning of a word is that part of it that the listener relies on in the process of recognizing the sounding word. As a result, the beginning of the word seeks to preserve its identity. It is a kind of "stronghold of reliability" that is used by listeners in the perception of speech. Therefore, those words in which the stress falls on the initial syllable are easily perceived [4]. One of the features of listening to a text in a foreign language is the use of the so-called "compensatory strategy", that is, compensating for gaps in the knowledge of vocabulary or grammar by listeners by referring to a linguistic guess [7]. The compensatory strategy works when there is redundant information in almost every speech utterance. The listener should strive to obtain the necessary information from the sounding text in a foreign language, without trying to understand every word of the utterance. In the methodological literature, one can find a statement that the development of listening skills should be carried out on the material of those types of texts that students will encounter in real life. Examples of these types of texts boil down to the following: news, lectures on academic subjects, announcements on radio or television, instructions, interviews, and so on [5]. Is such a gradation sufficient and does it help an adequate perception of information? Does the distribution of texts in terms of content contribute to the formation of a compensation strategy? We believe that it certainly does, but only partially. What, in this case, should be taken as the basis for teaching the perception of a sounding text in English lessons? In our opinion, this is an appeal to the discursive analysis of the text. On the one hand, discourse is addressed to a pragmatic situation, and speech is viewed as a communicative component aimed at communicating between people or communicating necessary information. From this point of view, the allocation of such 230 types of texts as news, lecture, weather report, announcement is quite justified. On the other hand, the discourse reflects the mental actions of the participants in communication and is built according to "... the rules and strategies for generating and understanding speech in certain conditions that determine ... the degree of its coherence, the ratio of the general and the specific, the new and the known, subjective and generally accepted, explicit and implicit ..." [6: 137]. Consequently, another gradation of texts is needed, based on intratextual relations. Such a gradation may include, for example, such texts, the discourse analysis of which reveals a causal structure; structure: "problem and its solution"; "The situation and its 
assessment" and so on. A step towards understanding the multidimensionality of a sounding text is to refer to the discourse markers of this text. The teacher should point out that the speech flow signals that lead to understanding the meaning of the text are always phonetically designed. The appeal to the prosodic characteristics of the text is directly related to the idea of a compensation strategy.

It is known that in order to understand a sentence, it is not necessary to recognize all its constituent words. The context often helps to restore the unheard word, and even if such a "restoration" does not take place, then understanding the meaning of the sentence as a whole is by no means excluded" [3: 306]. Zinder L.R. points to the linguistic meaning of intonation, saying that there are generally accepted models that speakers use, otherwise they would not be understood by the interlocutors: to explain the fact that thousands of listeners generally equally perceive what was said by an actor, reader or orator" [3: 306]. In our opinion, basic intonation contours can be characteristic for a number of languages, while emotional models can vary significantly. From the practice of teaching English, it is obvious that students understand well the basic intonational meanings of the melodic pattern of the English language: question, approval, surprise, protest, disagreement, and so on. In linguistic literature, there are many descriptions of the different organization of the text, based on its phonetic nature. Many researchers, for example, refer to the paragraph as the bearer of a complete thought. Monologue speech is characterized by pronouncing the first syntagma of a paragraph in a wider range of voice and narrowing the pronunciation range towards the end of the sounding paragraph [1]. Knowing this feature of pronunciation helps to understand the moment when the speaker begins to communicate new information. In linguistics, such studies are quite well-known, which indicate that the descending-ascending and ascending tones are markers of information known to the interlocutors, and the descending tone of a word or phrase introduces new information [2]. There are a lot of prosodic factors that determine the discourse of a sounding text. Linguists consider the meaning of the speech rhythm of speech as a source of the prosodic organization of the text. For example, in the article by G.G. Molchanova, a rhythmic scheme consisting of three beats and then a drop in tone is analyzed [7]. This scheme is often used in reference to the basic concepts of human existence: "Three is an assessment" (it must be earned); Eat, pray, love (live by moral principles). A word that is new information is perceived as stressed, and a sign of stress may be some special sound quality that is quite typical of a stressed word. So, speaking about the situation in Texas caused by the unfavorable environmental situation, the BBC announcer uses the phrase "You could hear". The phoneme [h] in - hear\| is pronounced not as a glottal fricative, but as a flat-slit posterior-lingual sound. The pronunciation of the phoneme in this case is not unusual. This pronunciation is often found in the emotional speech of native speakers. Obviously, the modern understanding of discourse includes the grammar of the text, as well as the principles of constructing a discourse, taking into account extralinguistic factors. The analysis of the text includes the characteristics of the social environment, the personal characteristics of the interlocutors, the opinions and attitudes of the speakers, which are implemented in the language. The modern understanding of discourse is based not only on the information provided by the speaker, but is based on various types of knowledge that the listeners possess. Based on this knowledge, there is a strategy for selecting information that is most important for the listeners. P.G. Luzina emphasizes that when perceiving a text, there is a constant processing of internal cognitive reserves and the external situation of communication: "We are talking about the correlation in semantic-pragmatic information of what is said and what is implied" [5: 140]. This thought made us pay attention to what aspects of the functioning of the language the degree of reliability of the listeners' understanding of the sounding text in a foreign language is associated. The literature points to two models for describing the process of perceiving a sounding 
text: "bottom up" and "top down". The "bottom up" model analyzes the process of recognizing the phonemic and syllabic composition by the listener in order to understand the meaning of the perceived text. The top down model analyzes the listener's use of background knowledge to anticipate or guess what the speaker will say [8]. Until recently, it was believed that the most characteristic of an adequate perception of a foreign language text is the ability of an individual to correctly recognize individual words. It was believed that errors in understanding the sounding text lie in the inability to distinguish and correctly understand the sounding word.

The background knowledge that the students possessed helped them understand the foreign test without much difficulty. Teaching listening at a university should be based on special principles, taking into account the fact that working with a sounding text has its own specifics, based on the patterns of constructing an oral message in a foreign language. First of all, classes aimed at teaching the perception of foreign speech by ear should include training in the perception of the phonetic features of the text. In addition, special attention should be paid to the discursive analysis of the sounding text and the ability of students to recognize signals in the speech stream that indicate the peculiarities of the discourse of the presented message. Making use of the background knowledge of students, which is designed to make it easier to understand the spoken text, is an integral part of the learning strategy in the listening class.

\section{REFERENCES:}

1. Бурая Е.А., Галочкина И.Е. и др. Фонетика современного английского языка. Теоретический курс. М.: Издательский центр «Академия», 2006. - С. 271.

2. Галочкина И.Е., Шевченко Т.И. Мелодика и ритм как составляющие социокультурной компетенции. Вестник МГЛУ. - 2010. - вып. 1 - (580). - С. 42-54.

3. Зиндер Л.Р. Общая фонетика и избранные статьи. 2-е изд., испр. и доп. СПб.: «Академия», 2007. - С. 575.

4. Лебедева Л.Д. Некоторые аспекты современных исследований пограничных сигналов в английском дискурсе. Вестник МГЛУ. - 2010. - вып. 1 - (580), - С. 91-99.

5. Лузина Л.Г. Виды информации в дискурсе. В сб.: Дискурс, речь, речевая деятельность. М.: РАН, 2000. - С. 137-154.

6. Labov W., Ash S. The Atlas of North American English. Phonetic, Phonology and Sound Change. Mouton de Gruyter, 2006. - P. 526.

7. Wilson J. How to Teach Listening. Pearson Education Limited, 2008. - P. 192.

8. Khudoyqulova D.K., Abdullaeva A.E. Psycholinguistic features of teaching listening to students of higher educational institution. Central asian journal of theoretical and applied sciences. 2021. Volume 2, № 01. - P. 10-13. 